https://helda.helsinki.fi

Conceptions of plagiarism and problems in academic writing in a changing landscape of external regulation

\title{
Löfström, Erika
}

2017-08

Löfström , E , Huotari , E \& Kupila , P 2017 , ' Conceptions of plagiarism and problems in academic writing in a changing landscape of external regulation ' , Journal of Academic Ethics , vol. 15 , no. 3 , pp. 277-292 . https://doi.org/10.1007/s10805-017-9285-y

http://hdl.handle.net/10138/234621

https://doi.org/10.1007/s10805-017-9285-y

unspecified

acceptedVersion

Downloaded from Helda, University of Helsinki institutional repository.

This is an electronic reprint of the original article.

This reprint may differ from the original in pagination and typographic detail.

Please cite the original version. 


\title{
ALMOST FINAL VERSION
}

\section{To cite, please refer:}

Löfström, E., Huotari, E., \& Kupila, P. (2017). Conceptions of Plagiarism and Problems in Academic Writing in a Changing Landscape of External Regulation, 15(3), 277-292. Journal of Academic Ethics. DOI: 10.1007/s10805-017-9285-y

\section{Conceptions of plagiarism and problems in academic writing in a changing landscape of external regulation}

\author{
Löfström, Erika, Huotari, Elisa, \& Kupila, Pauliina
}

\begin{abstract}
Objectives: The aim of this study was to investigate the consequences of the use of text-matching software on teachers' and students' conceptions of plagiarism and problems in academic writing.

Method: An electronic questionnaire included scale items, structured questions, and open-ended questions. The respondents were 85 teachers and 506 students in a large Finnish university. Methods of analysis included exploratory factor analysis, t-test, and inductive content analysis.

Results: Both teachers and students reported increased awareness of plagiarism and improvements in writing habits, as well as concerns and limitations related to the system. The results suggest that teachers are inclined to think of plagiarism as part of a learning process rather an issue of morality, which may have consequences for how they understand the role of text matching. The introduction of text-matching software has supported teachers' work, but at the same time teachers emphasized their own responsibility in detecting problems in student writing. The survey provides a limited sample of "Case Finland," where implementation of text-matching software nationwide has been remarkably rapid; it offers a glimpse into one institution's implementation of a newly introduced policy for mandatory plagiarism detection.
\end{abstract}

Keywords: academic writing, conceptions of plagiarism, text-matching software, student plagiarism

\section{Introduction}

Plagiarism has gained considerable attention in $21^{\text {st }}$-century research, apparently because it is perceived as a growing problem in universities. While there is increasing awareness of the processes of academic writing (e.g., Lonka 2003; Boscolo, Arfé and Quarisa 2007; Hyytinen, 
Löfström and Lindblom-Ylänne 2016), simultaneously, there is an increasing reliance on textmatching software, as shown by a wealth of research on plagiarism (e.g., Savage 2004; Evans 2006; Dahl 2007; Ledwith and Risquez 2008; Rolfe 2011). The literature thus suggests that the landscape of teaching and learning academic writing in higher education has undergone major changes since the turn of the century.

Four main lines of views on plagiarism have been identified: plagiarism as a moral problem, plagiarism as procedural matter, a developmental approach and an inter-textual approach (for a nuanced discussion see Kaposi and Dell 2012; also Sutherland-Smith 2014). Conceptually, plagiarism is often associated with misconduct, along with fabrication, falsification, and the more general concept of dishonesty (Jordan 2013), thereby placing it in the realm of moral transgressions. The approaches that appear to gain ground among authors in the field focus on academic literacy and related learning processes rather than plagiarism as such. These approaches pay attention to academic writing as social and ideological practice (Street 2004). They also pays attention to challenges faced by students for whom English is a foreign language, and by non-Western students learning to master Western conventions in academic writing. Plagiarism is treated as an issue arising from cultural differences, ideologies and consequently different expectations rather than as moral problems and transgressions of good practice (e.g., Pecorari 2003; Hayes and Introna 2005a; Hayes and Introna 2005b; Valentine 2006; Abasi and Graves 2008; Gu and Brooks 2008; Hirvela \& Du 2013). In their previous educational experience, these students may have been exposed to learning cultures in which the focus is on text memorization and recitation rather than on synthesizing knowledge and expressing themselves in their own words. Furthermore, literature recognizes disciplinary and situational differences. From the perspective of learning, the view on plagiarism as a moral transgression brings attention to punishment, which can be harmful for students' learning process as it prevents students from experimenting with their writing and expression (Angelil-Carter 2000). .

Research on reasons for plagiarizing shows that issues of both learning process and morality contribute to plagiarism. Intentionality may be a worthwhile pointer as to how to approach the issue of plagiarism (e.g. Introna and Hayes 2005b; Sutherland-Smith 2005; Löfström and Kupila 2013). Academic staff and students have been shown to regard students' lack of writing skills (i.e. unintentional reason) as the most common reason for plagiarism. Trouble with time management (i.e. intentional, but context-specific plagiarism, cf. Wilkinson 2009; Löfström and Kupila 2013), the ease of finding, copying, and pasting texts from the Internet (i.e. intentional plagiarism, cf. 
Power 2009; Comas-Forgas and Sureda-Negre 2010), the perceived small chance of getting caught, laziness, and a wish to obtain higher grades with less effort (Wilkinson 2009; Power 2009) are also reported as reasons for plagiarism. However, it should also be noted that the view according to which the Internet has increased plagiarism has also been contested (cf. Davies and Howard 2016). While the latter reasons might be argued to be issues of individual morality, viewed in an institutional perspective they place assessment practices and the conception of learning that an institute communicates to its students in the focus. Thus, focusing on plagiarism as an issue of individual morality misses to regard the role of institutional values, structures, and incentives (cf. Bertram Gallant and Kalichman 2011).

There is a fairly substantial body of literature on perceptions of plagiarism (e.g. Ashworth et al. 1997; Sutherland-Smith 2005; Breen and Maassen 2005; Pickard 2006; Abasi and Graves 2008; Power 2009; Gullifer and Tyson 2010; Löfström 2011), but less on the direct experiences and consequences of the use of text-matching software on conceptions, experiences and behaviors. Our review of the literature on academics' and students' experiences of the use of text-matching software indicates that students have reacted positively to the use of text-matching software, yet simultaneously they have identified limitations to those systems and raised concerns over their utility (Savage 2004; Evans 2006; Dahl 2007; Ledwith and Risquez 2008; Rolfe 2011). Students who feel confident about their academic writing competence react more positively to text-matching than students who are unsure of their writing skills and their competence to avoid plagiarism (Dahl 2007). Among the positive aspects of text-matching, students have identified the ease of use, that is, the software does not interfere with studying and turning in tasks, and the fact that such a system makes it more difficult to get away with plagiarism (Dahl 2007; Evans 2006; Ledwith and Risquez 2008). Furthermore, it has been shown that students value the chance for feedback from the originality reports produced by these systems. The use of text-matching software has been shown to influence students' learning and behavior. Based on the originality reports produced by these systems, students have been able to improve their writing by developing citation techniques and paraphrasing sources in their own words (Davis and Carroll 2009). Students have been reported to regard text-matching software as reliable in detecting plagiarism, although some have also found originality reports to be incorrect and confusing (Dahl 2007). Students have reported further concern that the availability of text-matching software will lead to teachers not reading their texts, but relying solely on the system-produced reports, which would hamper students' opportunities to receive feedback on the content of their work (Savage 2004). Furthermore, students may be concerned about legal issues related to privacy (Savage 2004) and the impression that the use of 
text-matching software signals a basic distrust of students; consequently, they have to prove their innocence (Evans 2006; Savage 2004, Löfström and Kupila 2013). Students have also reported that the use of text-matching software influences the learning atmosphere negatively, making students scared, insecure and uncomfortable (Dahl 2007).

Prior research has shown that text-matching software support teachers in detecting plagiarism and making student assessments (Savage 2004; Martin 2005; Evans 2006; Badge, Cann and Scott 2007; Crisp 2007). Teachers report that the use of a text-matching software has increased students' awareness of plagiarism and state that the feedback offered in the originality reports is useful for the students (Rolfe 2011). Teachers view text-matching software as being beneficial, because students pay more attention to their writing (Savage 2004). On the more critical side, teachers have reported that using text-matching software is time consuming and unreliable (Savage 2004; Badge, Cann and Scott 2007. Rolfe 2011). Challenges reported include issues with functionality of text-matching software, interpretation of results, false positives and false negatives, and database issues including copyright (Weber-Wulff 2016). (There is some evidence for change in behaviors as a consequence of the use of text-matching software (Savage 2004; Davis and Carroll 2009), but also contrary evidence has been presented where the use of text-matching software has not been related to instructor behavior or conceptions (Bennett et al. 2011). Overall, compared to conceptions of plagiarism and text-matching, less is known about the impact of institutional introduction of the use of text-matching software on university teachers' and students' conceptions of plagiarism and academic writing. Thus, we posed the following question: "What are the consequences of the introduction of institutional text-matching softwareon academics' and students' conceptions of plagiarism and academic writing?" Where relevant, we attempt to view the findings in light of the paradigms of plagiarism presented above.

\section{Method}

\section{Context}

Since the beginning of the $21^{\text {st }}$ century, text-matching software has been systematically introduced into Finnish higher education. While this is fairly late by international comparisons, this comprehensive introduction has taken place rapidly. By 2014, text-matching software had been taken into use in 34 higher education institutions (i.e., universities and universities of applied sciences) that is, in 83 percent of higher education institutions in the country. Key national priorities 
regarding the introduction and use of text-matching software on the national level were related to administrative matters (e.g. authentication, development of procedures), to developing the functionality of systems (e.g. developing databases for text-matching purposes), and to connect the use of text-matching software with teaching and learning processes, including the teaching of responsible conduct in research (Tuhkanen 2014). The last priority involves issues of purpose of use, pedagogy, and learning.

Two commercial systems, Turnitin and Urkund, dominate the landscape of text-matching in Finland. The study captured the first reactions to the implementation of a newly introduced policy. The study was conducted in a large university at the time it had become mandatory (2015) to check all master's theses by means of text-matching software. This decision was preceded by a one-year piloting of two software in 2011, the decision to purchase one of these in 2012, and its implementation in 2013. Movements at different levels of the system including top-down and bottom-up initiatives simultaneously played a part in the developments. The piloting was triggered by queries from teachers and administrators from various departments to the university's educational technology centre about the possibility of using text-matching software. While some departments and individual teachers had acquired access to software, there was no system in place at the institutional level. The pressure to offer a tool to teachers and administrators led the Center to launch the pilot project, the results of which have been reported in Löfström and Kupila (2013). In connection to the decision to implement text matching in 2012, the university renewed its internal policy and procedures on student plagiarism, and produced a web site to inform both teachers and students about the new policy and the use of text-matching software, and to provide guidance in academic writing. In the same year, the university also published ethical principles for teaching and studying. The promotion of integrity received attention nationally as well as the national guidelines on the responsible conduct of research and procedures for handling allegations of misconduct in Finland from 1994 (revised in 1998 and 2002) were revised and updated in the same year (Finnish Advisory Board on Research Integrity 2012).

Today, in seven of the eleven faculties of the university, text-matching software has been integrated into an electronic thesis database that runs all submitted theses automatically through the text-matching procedure. In three faculties also bachelor's theses are checked automatically. In addition, the institutional policy outlines that teachers may use the software to systematically check other student works besides theses; to check individual pieces of work as needed; and to use the software as a support in teaching academic writing. However, the results from the pilot project 
showed that teachers primarily used the software for checking student work, and only rarely as a support in supervision and teaching (Löfström and Kupila 2013).

Retrospectively, the unfolding of the events followed the plagiarism quality assurance model proposed by Sutherland-Smith (2014). Discourses of legality, quality assurance, and learning intertwined in the process. On the institutional level the implementation of the use of text-matching software was a response to internal and external changes. The implementation was preceded by a research-intensive pilot (cf. institutional self-evaluation). The institutional processes were developed by establishing an internal policy and procedures. Teaching and learner experiences were taken into account by outlining the uses of the software (including use in teaching and as support in teaching academic writing), creating a supporting web site for teachers and students, and offering training to teachers. Between 2013 and 2015 fifty-seven non-mandatory training sessions focusing on software features and use as well as pedagogy were organized, and 765 academic and administrative staff members participated in these trainings. This equals to roughly 10 per cent of the total number of staff at the university. Despite the training, teachers may not be prepared to handle to the emotional burden associated with dealing with student plagiarism (cf. Vehviläinen et al. 2017).

\section{Participants and ethics}

The participants in the study were university students at all stages of study and academic staff. All were registered users of a text-matching software at a large university in Finland. Questionnaires were sent to 920 teachers and 6,563 students of whom 85 teachers and 506 students responded. The response rates were rather low: 8 percent among students and 9 percent among teachers.

Of the students, about 40 percent were in their first, second, or third university year, a little over 30 percent in their fourth or fifth year; less than 30 percent had studied more than five years. The academic staff included professors, university lecturers, and other staff members who provided teaching or supervised theses and consequently were users of the text-matching software. In presenting the results, we refer to all academic staff members as teachers. Two thirds had more than 10 years of university teaching experience. Seventy-four per cent of the students and 51 percent of the academic staff were women, roughly reflecting the overall gender distributions of students (64\% women) and academic staff members (50\% women) throughout the university. The fields represented in the study included education, psychology, law, humanities, theology, social sciences, natural sciences, medicine, biological and environmental sciences, veterinary science, pharmacy, and agriculture and forestry. 
Participation was voluntary. A drawing of two gift cards was held for students. No identifying information was collected in the survey. In order to participate in the drawing, students could leave their contact information, but this information was not connected with the survey responses. The study did not require an ethics review (cf. guidelines for ethics review, Finnish Advisory Board for Research Integrity 2009).

\section{Data collection and survey instrument}

The research was carried out as a survey-type study using an electronic questionnaire available in Finnish, Swedish, and English in order to reach both domestic and international staff and students. The questionnaire was sent to all prospective participants, that is, the registered users of the textmatching software. The questionnaire, adapted for students and teachers respectively, included fixed choice items on a 5-point Likert-type scale, structured questions, and open-ended questions (cf. Löfström and Kupila 2013). Open-ended questions were used to explore how the use of textmatching software had influenced teachers' and students' perceptions of plagiarism and teaching/studying ("If you have used text-matching software, has it changed your views about plagiarism and text-matching? Please describe the factors that have influenced your views."). We felt that asking only about changes in views would not be sufficient without information about where the academics and students in the sample stand on, in general, in questions related to forms, frequency and reasons (intentional or not) for plagiarism in their university. Thus, we investigated the students' conceptions of plagiarism using items that described sham paraphrasing, verbatim plagiarism, and purloining as defined in Walker (2010). The response alternatives were "don't know," "not plagiarism," "is plagiarism, but not a serious form of it," "is a somewhat serious form of plagiarism," and "is a very serious form of plagiarism." We also asked the teachers how common they perceived these forms of plagiarism to be, and we asked the students how common they thought plagiarism to be in general among university students. The response alternatives were “don't know," "very uncommon," "quite uncommon," "quite common,” and "very common.” In addition, we asked whether the teachers and students believed plagiarism was a problem in their discipline, with response alternatives "don't know," "not a problem," "relatively minor problem," “relatively big problem, and "big problem." The above questions do not tap into the role of intentionality in plagiarism, we used the scales on Reasons for Plagiarism in order to understand whether teachers and students view plagiarism as intentional or non-intentional. While this does not directly provide insight in whether or not respondents regard plagiarism as a moral transgression or part of a novice writer's strategic repertoire, it does give an indication of the approach (moral or 
academic literacies, cf. Street 2004; Kaposi and Dell 2012; Sutherland-Smith 2014) a respondent takes.

\section{Methods of analysis}

The open-ended questions were analyzed applying inductive content analysis (Vaismoradi, Turunen, and Bondas 2013). First, the contents of teachers' and students' responses were simplified (Table 1). Then responses containing similar themes were combined into categories. Responses containing several themes were divided up and grouped into appropriate categories. After the categorization made by one of the authors, another author checked 60 percent of the coding. The interpretations of the authors were identical on 96 percent of the responses, which can be considered indicative of a substantial degree of inter-rater reliability (cf. Mitchell and Jolley 2013). Based on the double checking, a few responses were categorized differently, based on the second rater's suggestions. At this stage, category titles were adjusted to reflect any changes in the coding.

Table 1: Example of categorization of two data excerpts.

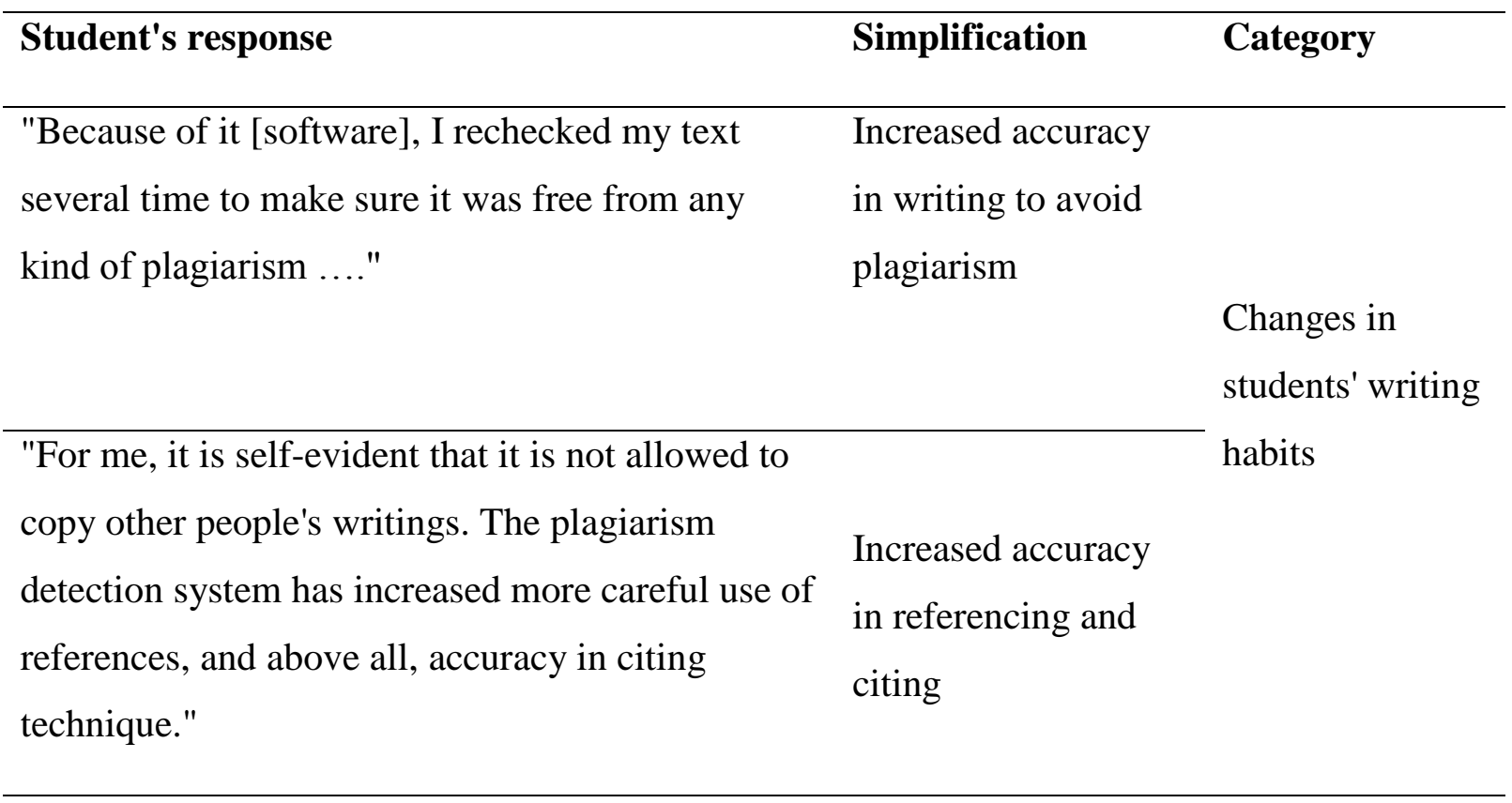

The statistical methods of analysis included exploratory factor analysis with Varimax rotation and ttests with Cohen's $d$ to indicate effect sizes. Exploratory factor analysis was performed on the Reasons for Plagiarism scales. Three factors with an eigenvalue $>1$ were extracted (Table 2). The first factor was called Intentional plagiarism (Cronbach's $\alpha=.75)$ with an acceptable reliability 
(George \& Mallery, 2003). It included items reflecting the view that plagiarism is a consequence of deliberate action, often justified because of its common nature or because potential gains outweigh the costs (items 3, 4, 5, 6, and 7). The eigenvalue was 2.72 and the factor explained 30 percent of the variance. The second factor was called Contextual plagiarism and it showed good reliability (Cronbach's $\alpha=.83$ ). The factor included items reflecting the view that, while plagiarism is the consequence of deliberate action, students resort to such behavior only as a last resort under pressing circumstances (items 8 and 9). It had an eigenvalue of 1.71 and explained 19 percent of the variance. The third factor was called Unintentional plagiarism, but its reliability was weak and should be treated with great caution (Cronbach's $\alpha=.51$ ). It included items reflecting the view that plagiarism is the consequence of insufficient competence (items 1 and 2). Its eigenvalue was 1.20 , and it explained 13 percent of the variance.

Table 2: Factor analysis of Reasons for Plagiarism with factor loadings.

\begin{tabular}{llll}
\hline Item & Factor 1 & Factor 2 & Factor 3 \\
\hline $\begin{array}{l}\text { 5. Students plagiarize because they believe that the risk of } \\
\text { getting caught is less than the benefits gained. }\end{array}$ & .766 \\
6. The consequences and sanctions after a student has been & .623 & \\
caught plagiarizing are trivial. \\
3. Students don't think plagiarism is a serious offence. \\
$\begin{array}{l}\text { 4. Students plagiarize because their peers do it. } \\
\text { 7. Carelessness }\end{array}$ \\
$\begin{array}{l}\text { 8. Students are overloaded with too many writing assignments } \\
\text { and don't have time to do them all properly. }\end{array}$ \\
9. Students have various other obligations in life, e.g., family, \\
work, which prevents them from fully engaging in all study \\
assignments properly. \\
1. Not knowing the proper way to use sources and make \\
references to them. \\
2. In principle, students know how to write academic texts, \\
but they don't have sufficient skills to write properly, e.g., to \\
write things in their own words.
\end{tabular}




\section{Results}

Students' and teachers' perceptions of the forms, frequency and reasons of plagiarism in university studies

We begin by reporting the status quo of teachers' and students' conceptions of the forms, frequency and reasons for plagiarism in order to ground the qualitative data on changes in a description of where teachers and students currently stand. The students' conceptions of what constitutes plagiarism and what is serious plagiarism resonates with what the teachers observed in student works: The forms of plagiarism that the students regarded as serious were less commonly observed by the teachers. However, the forms of plagiarism that the students considered less serious breaches of integrity were more commonly observed by the teachers (Table 3). Students considered representing another students' work as one's own to be the most serious form of plagiarism. Almost all students (94\%) who responded considered this to be a very serious form of plagiarism. Simultaneously, 84 percent of teachers considered this to be a very uncommon form of plagiarism. However, almost half of the students (43\%) did not consider verbatim citation without quotation marks as a serious form of plagiarism, and an additional 14 per cent did not recognize this to be plagiarism. Of the teachers, more than half (55\%) regarded such plagiarism as either quite or very common. A majority of students considered the other forms of plagiarism to be either serious or very serious breaches (see Table 3). Most of the students (92\%) recognized that citing a text verbatim with reference to the original authors and using quotation marks is not plagiarism. However, 6 percent of the students indicated that this was plagiarism, suggesting that students are not always able to distinguish between plagiarism and normal referencing practice. 
Table 3: Students' conceptions of the seriousness of different forms of plagiarism and teachers' perceptions of the frequency of forms of plagiarism among students.

\begin{tabular}{|c|c|c|c|c|c|c|c|}
\hline & Students & & & & & Teachers & \\
\hline Item & $\begin{array}{l}\text { don't } \\
\text { know }\end{array}$ & $\begin{array}{l}\text { not } \\
\text { plagiarism }\end{array}$ & $\begin{array}{l}\text { not a } \\
\text { serious } \\
\text { form }\end{array}$ & $\begin{array}{l}\text { a somewhat } \\
\text { or a very } \\
\text { serious } \\
\text { form }\end{array}$ & don't know & $\begin{array}{l}\text { very or } \\
\text { quite un- } \\
\text { common }\end{array}$ & $\begin{array}{l}\text { quite or } \\
\text { very } \\
\text { common }\end{array}$ \\
\hline $\begin{array}{l}\text { Representing } \\
\text { parts of another } \\
\text { student's work as } \\
\text { one's own }\end{array}$ & total $\mathrm{f}=506$ & $0.2 \%$ & $5.9 \%$ & $93.7 \%$ & $\begin{array}{l}\text { total } \mathrm{f}=84 \\
11.9 \%\end{array}$ & $84.5 \%$ & $3.6 \%$ \\
\hline $\begin{array}{l}\text { Representing } \\
\text { another student's } \\
\text { entire work as } \\
\text { one's own }\end{array}$ & total $\mathrm{f}=504$ & $0.4 \%$ & - & $99.4 \%$ & total $\mathrm{f}=85$ & $87.1 \%$ & - \\
\hline $\begin{array}{l}\text { Representing } \\
\text { another student's } \\
\text { work as one's } \\
\text { own with the } \\
\text { permission of the } \\
\text { student }\end{array}$ & total $\mathrm{f}=505$ & $3.4 \%$ & $16.6 \%$ & $78.6 \%$ & total $\mathrm{f}=84$ & $82.1 \%$ & $3.6 \%$ \\
\hline $\begin{array}{l}\text { Representing } \\
\text { someone else's } \\
\text { text as one's own } \\
\text { without reference } \\
\text { to the original } \\
\text { author(s) }\end{array}$ & total $\mathrm{f}=505$ & $0.2 \%$ & $4.4 \%$ & $95.0 \%$ & total $\mathrm{f}=85$ & $68.2 \%$ & $30.6 \%$ \\
\hline $\begin{array}{l}\text { Citing text } \\
\text { verbatim with } \\
\text { reference to the } \\
\text { original author(s), } \\
\text { but without } \\
\text { quotation marks }\end{array}$ & total $\mathrm{f}=506$ & $14.2 \%$ & $43.1 \%$ & $39.1 \%$ & total $\mathrm{f}=85$ & $43.5 \%$ & $55.3 \%$ \\
\hline $\begin{array}{l}\text { Citing text } \\
\text { verbatim with } \\
\text { reference to the } \\
\text { original author(s), } \\
\text { and using } \\
\text { quotation marks }\end{array}$ & total $\mathrm{f}=506$ & $92.3 \%$ & $3.2 \%$ & $3.2 \%$ & & & \\
\hline
\end{tabular}


A majority of the students $(\mathrm{f}=407,81 \%)$ considered plagiarism in general to be uncommon or very uncommon in university studies $(\mathrm{M}=1.80 ; \mathrm{SD}=0.56)$. Seven percent considered plagiarism quite common and none considered it very common. Thirteen percent were unable to provide an approximation of the frequency of plagiarism.

Both teachers and students were asked how common they estimated plagiarism to be within their discipline. Overall, while both tended to believe that plagiarism was not a problem or only a minor problem (Teachers: $\mathrm{M}=1.79 ; \mathrm{SD}=0.60 ;$ Students: $\mathrm{M}=1.56 ; \mathrm{SD}=0.64$ ) there was a statistically significant difference at a $p<.05$ level suggesting that the teachers regard plagiarism as a slightly bigger problem than the students. However, the effect size was small $[\mathrm{t}(123.88)=3.11, p<.05$, Cohen's $d=.37$ ]. Only 5-7 percent estimated plagiarism either as a rather major problem or as a major problem within their discipline. Unintentional plagiarism was reported to be the most common reason for plagiarism $(\mathrm{N}=591, \mathrm{M}=2.64, \mathrm{SD}=0.68)$ with Contextual plagiarism $(\mathrm{M}=2.05$, $\mathrm{SD}=0.74$ ) considered as a less typical reason. Intentional plagiarism was regarded as the least common reason for plagiarism $(\mathrm{M}=1.81, \mathrm{SD}=0.48)$. The teachers more often than the students estimated plagiarism to be unintentional (Teachers: $n=85, M=2.79, S D=0.76$, students: $n=506$, $\mathrm{M}=2.62, \mathrm{SD}=0.66$ ). The difference was statistically significant at the $p<.05$ level and with a small effect size $[\mathrm{t}(106.155)=2.03, p<.05, d=0.25]$.

A comparison of study years showed that there is a difference between second- and fifth-year students. The second-year students $(\mathrm{n}=55, \mathrm{M}=2.75, \mathrm{SD}=0.57)$ regarded unintentional plagiarism as much more common compared to the fifth-year students $(\mathrm{n}=66, \mathrm{M}=2.50, \mathrm{SD}=0.66)$. The difference was statistically significant at a $\mathrm{p}<.05$ level with a rather small effect size $[\mathrm{t}(119)=2.176, p<.05, d=$ $0.40]$. Also, the undergraduate students $(n=433)$ considered contextual plagiarism as a more common reason for plagiarism $(M=2.10, S D=0.75)$ than did the postgraduate students $(n=31$, $\mathrm{M}=1.73, \mathrm{SD}=0.74),[\mathrm{t}(462)=2.56, p<.05, d=0.48]$. There was a medium effect size.

Influences of a text-matching software on teachers' and students' conceptions of plagiarism and academic writing 
The use of the text-matching software has influenced teachers' work and perceptions of plagiarism. In the teachers' responses, four categories of changes in views were identified as follows (the number of times is mentioned in parentheses): the system as a support for teacher's work $(\mathrm{f}=12)$; recognition of teacher's increased responsibility in detecting plagiarism ( $\mathrm{f}=4)$; the possibility of ensuring students' honesty through text-matching software $(\mathrm{f}=4)$; and a critical view sustained or strengthened $(f=7)$.

Teachers described how the use of the text-matching software had supported their work $(\mathrm{f}=12)$. They reported that the system had helped them to explain and justify to their students why it is important to follow certain conventions in academic writing. They also reported that students had begun to pay more attention to their writing. One of the teachers described the positive effects of the system in the following way: "I think the use of a plagiarism detection system by the university has made it very clear to students how seriously the university takes plagiarism. I teach an academic writing course, and the students pay a lot more attention to academic writing standards when they realize that there are sanctions for plagiarism." Teachers reported that the system had made the detection of plagiarism easier. Moreover, the system had not only been a tool to detect plagiarism, but also had made it transparent that many students do not appear to have problems with their writing ( $\mathrm{f}=4$ ). This was perceived to be reassuring, as the following quotation from one teacher shows: "Delightfully, the similarities [to pre-existing texts] in many students' essays' after system checking was 0\%." Of course, the percentages in themselves do not constitute proof of plagiarism or the lack of it, but we read the teachers' comment as an expression of relief over what is perceived as evidence that one may fundamentally trust the students. Several teachers indicated that they will have problems doing their work if they must begin to distrust their students. The pedagogical relationship is essentially a relationship of trust, and the use of text-matching software potentially introduces the idea that teachers should be more vary of students' honesty.

Despite the introduction of the text-matching software, teachers emphasized their own responsibility in detecting plagiarism ( $\mathrm{f}=4$ ). This was regarded as important because the system's checking was not perceived as entirely reliable. The teachers remarked that it remains their responsibility to read students' assignments, as the following quotation shows: "The system is not able to detect all forms of plagiarism, but the teacher has to be attentive when reading students' assignments. The use of text-matching software does not allow the teacher to disregard 'manual' checking." It appears that teachers may be concerned about over-reliance on the software and disregard for the intentionality and nature of the problems in students' writing. 
Some teachers had critical views of the text-matching software $(\mathrm{f}=7)$. The explicitly critical opinions mainly concerned the reliability of the system. The system's capacity to detect translation plagiarism and the range of sources covered in the database triggered questions about the system's utility. As one teacher put it: "Yes, I think it is not fully effective as a system, particularly when there are students copying each other's assignments. Moreover, there is the possibility that students switch languages, and this way it is quite impossible to reveal the plagiarized source." The responses that criticized the reliability of text-matching software appeared to incorporate the view that plagiarism as more or less intentional, and that an optimal tool would have the capacity to sift out the various ways in which students might plagiarize.

In the students' responses, we identified seven categories of how the text-matching software had influenced their conceptions of plagiarism and academic writing, as follows: changes in students' writing habits $(\mathrm{f}=42)$; students' negative feelings and feelings of academia's mistrust of students $(\mathrm{f}=23)$; recognition of the seriousness of plagiarism $(\mathrm{f}=14)$; changed perceptions about the magnitude of plagiarism ( $\mathrm{f}=12)$; recognition of the necessity of using the system in plagiarism prevention $(\mathrm{f}=13)$; realization that the university takes plagiarism seriously $(\mathrm{f}=8)$; and identifying the limitations of the system $(f=7)$.

Many students described changes, primarily improvements, in their writing habits ( $\mathrm{f}=42$ ), such as increased accuracy in referencing, as demonstrated by the following quotation: "I got more detailed understanding; for instance, I started to pay more attention to paraphrasing ideas properly compared to the original source." The improvements in writing habits may have been influenced by students' concern about having accidentally plagiarized and being accused by their teachers. Students expressed this concern among other negative feelings about the use of text-matching software $(\mathrm{f}=23$ ). The concern of having plagiarized accidentally was sometimes related to a student's awareness of lack of competence: "I am not sure what is counted as plagiarism and what is not. I am afraid that single sentences which I have not been able to paraphrase correctly are regarded as plagiarism. I think that would not be fair, because it is difficult to express some things in one's own words." The difficulty of expressing an idea for oneself appears to be indicative of other problems. For instance, students may be focused on repeating detailed facts in their written works, but struggle to grasp bigger ideas and are not able to synthesize the knowledge they have gained if they are using writing strategies that merely reproduce their sources. Some students felt that the introduction of such a system was a sign that the academic staff mistrusted them. At the 
same time, students recognized that, although they felt bad about the new policy on an individual level, there were benefits when considering the bigger picture. One student expressed this in the following way: "The use of the system makes me feel a little bit like students are not trusted. On the other hand, it would be embarrassing for the university if someone had really plagiarized and was not caught immediately. It could the put the department's reputation at risk." Serious cases of plagiarism, or any form of academic misconduct, might put the reputation of an institution at risk. The student's comment is interesting precisely because it is presented by a student. It raises questions about what institutional values are communicated to students. One might hope that the institutional priority of student learning would be at least as strong as that of reputation management. The role of reputation in academia cannot be underestimated, not least because of the pronounced role of university ranking tables. However, from the perspective of learning, a trusting and respectful learning environment in which high expectations along with high support are communicated, is likely to facilitate student thriving.

Students reported paying attention to the fact that the university actually deals with plagiarism $(\mathrm{f}=8)$ : "It [the software] reinforces the notion that the university takes plagiarism seriously, which is a good thing. "Such statements appear to be underpinned by the expectation that the institution treats its students equally and fairly. Furthermore, students' responses showed that students themselves had begun to regard plagiarism as a more serious breach since the introduction of the system ( $\mathrm{f}=14)$ : "The use of the software reveals ethical questions related to plagiarism and has gotten me to thinking more about it." Students also reported how their perceptions of the magnitude of plagiarism in university studies had changed $(\mathrm{f}=12)$. They expressed disbelief that some students plagiarize at the university level: "It [the system] has made it real 'the possibility' that someone would plagiarize. I would have never imagined that someone would do something like that on the tertiary level of education." Some students regarded the system as an essential tool in plagiarism detection and prevention ( $\mathrm{f}=13$ ). Like the teachers, the students too felt that the system had made it is easier to spot plagiarism: "As far as I know, thanks to the system at least the obvious cases can be detected more easily today." Students considered it to be only fair that those who intentionally plagiarize be caught. There appeared to be the underlying notion that what the text-matching software reports is indicative of both plagiarism and intentionality. Similarly to teachers, students also identified the limitations of the system $(\mathrm{f}=7)$ : its inability to detect translated plagiarism, false similarities, shortcomings related to the reference database, and collusion all were mentioned in students' responses. 


\section{Discussion}

The study has shed light on how the introduction of text-matching has influenced academics' and students' conceptions in the context of renewed institutional policy. The introduction of textmatching software supported teachers' work, but at the same time the teachers emphasized their own responsibility in the detection of challenges in student writing. Both the teachers and the students reported increased awareness of plagiarism, improvements in writing habits, and also concerns about the limitations of the software. Of these, the inability of the system to detect translated plagiarism, false similarities, shortcomings related to the reference database, and collusion have been identified in other studies (e.g., Ellis 2012; Weber-Wulff 2016). However, the concern voiced elsewhere (Ellis 2012) that teachers will cease to be vigilant and instead place full trust in the system's capacity to identify the problems is not supported in this study. On the contrary, teachers emphasized the importance of reading student assignments with attention to problematic writing strategies.

The results show that, according to the teachers, students engage more often in those forms of plagiarism that the students did not consider to be serious breaches of integrity. The finding suggests placing greater emphasis on explaining to students why forms of plagiarism that they consider less serious might also be problematic. Students may not always comprehend how the creation of new knowledge is an accumulative process in which appropriate crediting allows readers to follow the process of knowledge creation. Furthermore, students may not be aware that the way in which contributors are credited is consequential for researchers and institutions. Also, students may not associate the assignments or theses they themselves produce with knowledge creation. The introduction of text-matching software will not automatically address these issues. While it may increase awareness of plagiarism as a phenomenon, it does not promote the understanding of knowledge-creation as an accumulative and cultural process unless these ideas are introduced by teachers.

It is hardly surprising that teachers considered plagiarism to be more common than students do. Teachers are exposed to a variety of writing styles and thus possess a broader view of the range of student writing strategies. The reasons found for plagiarism show that teachers are often inclined to view problems in students' writing as a learning process. This is reflected in the result showing that teachers generally consider plagiarism to arise from lack of knowledge and writing competence. 
Also previous research has shown that undergraduate students are often unaware of the conventions of academic writing (Breen and Maassen 2005; Jurowska and Thompson 2012). Novice students may know the definition of plagiarism because they have been told about it, but they have difficulty understanding what constitutes plagiarism in practice (Roig 1999; Power 2009; Gullifer and Tyson 2010). For instance, students may believe that they do not need to provide a reference if they paraphrase a source text (Power 2009). Students may also have difficulty understanding what constitutes plagiarism beyond obvious examples (Gullifer and Tyson 2010). "Patch writing" means copying text and deleting words, substituting synonyms and changing sentence structure (Howard 1999; cf. also Pecorari 2003; Hayes and Introna 2005b; and Jamieson 2016 for a discussion of the concept). This is a strategy that could indicate plagiarism, but could also be a beginning writer's technique to create text from a number of different sources (e.g. Howard 1995; Hayes and Introna 2005b; Davis 2013; Hyytinen et al. 2016). Recognizing writing strategies that resemble plagiarism is essential as these can be indicative of the students' developing competence in the process of learning to write in an academic genre. Therefore, it becomes necessary for teachers to understand how students conceptualize writing, what they understand the purpose of academic writing to be, and how they see themselves as writers. Text-matching software will not portray this information, but its use can potentially help to create space for discussion around students' understandings and conceptualizations if used in a pedagogical way. Furthermore, as Howard and Davies argue, problems in writing are related to problems in reading comprehension, and requires attention with appropriate instructional strategies (Howard and Davies 2009; Davies and Howard 2016). Teachers'

The overall conclusion we draw from these results is that the view that plagiarism is mostly a moral problem does not resonate well with the views of the teachers and students in our sample.

Potentially, this view may come into conflict the implementation of text-matching software if perceived as a tool for implementing a regulatory framework and exercising control unless teachers are able to find ways of utilizing the reports produced by the software for pedagogical purposes. At the same time, it is necessary to recognize that plagiarism is sometimes intentional, in which case it is a signal of an immature attitude to studying or problems in mastering one's studies. Poor strategies can be a symptom of underlying problems that need to be addressed first (Löfström and Kupila 2013). The fact that contextual plagiarism is more common among beginning students suggests that underdeveloped study strategies contribute to the problem. Students with more study experience have already developed better strategies (cf. also Wilkinson 2009) and do not feel the pressure to resort to intentional plagiarism as a way of coping with writing assignments or studies in general. 
We wish to caution against generalizing the results of the study. The response rate was low and the respondents represented a single institution. It is possible that teachers and students with particularly positive or negative experiences responded to the survey, while the majority who did not respond may feel neutral about text-matching software. Nevertheless, the survey provides a limited sample of "Case Finland," a country where implementation of text-matching software nationwide has been remarkably rapid, and has offered a glimpse into one institution's experiences of the implementation of a newly introduced policy of mandatory use of text-matching software. While based on the origins of research on student plagiarism it appears that Anglophone countries are internationally ahead in the implementation of text-matching, there may be regions globally in which the importance of publishing in English increasingly places demands on teaching academic writing skills in universities, and consequently may put pressure on monitoring students' work. The experiences reported by teachers and students in the present study, for whom the introduction of text-matching software changed their views about plagiarism and academic writing, may be useful in laying out the considerations that institutions may need to take into account in introducing policies on plagiarism.

First, based on the results of the study, we feel that it is particularly relevant to take into consideration the view frequently expressed by teachers that student plagiarism is unintentional. This implies that plagiarism is conceptualized more as a symptom of a learning process than as a moral problem. Thus, there should be fertile ground for introducing pedagogy as a means of addressing issues in writing. Training or other types of support for teachers during the introductory phases of text-matching software (cf. also Crisp 2007) should include pedagogical training in teaching academic writing. Davies and Howard (2016) point out text-matching software in itself is no guarantee for a pedagogically better informed approach, and this is also supported by our prior study that showed that teachers hardly utilized text-matching reports in supervision and teaching despite the fact that the institutional policy explicitly outlines the use of text-matching software as a support in teaching academic writing and supervising student writing (Löfström \& Kupila 2013). Serviss (2016) proposes a holistic faculty development model for preventing plagiarism. It begins with the introduction of research in order to provide conceptualizations of plagiarism; continues with evaluation of best practices for preventing plagiarism; engages faculty in self-study with the aim to identify areas that need further attention; and finally promotes academics to articulate an action plan together. 
In the phase of implementing institution-wide use of text matching software, institutions may also wish to consider training in the form of study strategy workshops for students along with pedagogical training for staff members. Placing emphasis on the development of students' study strategies signals that the institution wishes to support quality learning rather than just paying attention to catching students who cheat. While surely both aims prevail, focus on learning promotes the development of a culture of integrity proactively through a positive message (cf. Ferguson et al. 2007; also Ashworth et al. 1997).

Second, the introduction of text-matching software changes both teacher and student views of plagiarism and academic writing. While most changes reported by the participants in this study were positive, such as increased awareness and modified behaviors, there were also negative changes, such as students' feelings that the academic staff mistrusts them. Such experiences could be detrimental, given that trust is a vital element in relationships in a learning context. Otherwise, learners will not feel confident to expose their lack of knowledge and understanding; teachers on the other hand will not have a realistic view of the students' understanding and consequently will not design their teaching in a manner that appropriately supports learning. Furthermore, an increased focus on writing conventions may not automatically result in students' internalizing the values associated with academic integrity and good research practice (Ledwith and Risquez 2008). Therefore, it is essential that institutions pay attention to how they communicate their expectations about learning and integrity. This need becomes particularly poignant in light of the students experiences of the introduction of the use of text-matching software as a sign of distrust towards students and their morality. Ashworth and colleagues (1997) have highlighted the connection between alienation and cheating, and we believe that trust and respect are key in combating such alienation that might have negative consequences for student commitment to learning.

\section{Acknowledgments}

The authors would like to thank the anonymous reviewers for their helpful comments on an earlier version of the manuscript. This work was supported by the Academy of Finland [grant number 252813] to the first author.

\section{Disclosure statement}

No potential conflict of interest was reported by the authors. 


\section{References}

Abasi, A. R., \& Graves, B. (2008). Academic Literacy and Plagiarism: Conversations with International Graduate Students and Disciplinary Professors. Journal of English for Academic Purposes, 7(4), 221-233.

Angelil-Carter, S. (2000). Stolen language?: plagiarism in writing. London: Pearson education.

Ashworth, P., Bannister, P., \& Thorne, P. (1997). Guilty in whose eyes? University students' perceptions of cheating and plagiarism in academic work and assessment. Studies in Higher Education, 22(2), 187-203.

Badge, J. L., Cann, A. J., \& Scott, J. (2007). To cheat or not to cheat? A trial of the JISC plagiarism detection service with biological sciences students. Assessment \& Evaluation in Higher Education, 32(4), 433-439.

Bennett, K. K., Behrendt, L., \& Boothby, J. L. (20111). Instructor perceptions of plagiarism: are we finding common ground? Teaching of Psychology, 38(1), 29-35.

Bertram Gallant, T., \& Kalichman, M. (2011). Academic Ethics. A systems approach to understanding misconduct and empowering change in the academy. In T. Bertram Gallant (Ed.), Creating the ethical academy. A systems approach to understanding misconduct and empowering change in higher education (pp. 27-44). New York, NY: Routledge.Boscolo, P., Arfé, B., \& Quarisa, M. (2007). Improving the quality of students' academic writing: An intervention study. Studies in Higher Education, 32(4), 419-438.

Breen, L., \& Maassen, M. (2005). Reducing the incidence of plagiarism in an undergraduate course: the role of education. Issues in Educational Research, 15(1), 1-16.

Comas-Forgas, R., \& Sureda-Negre, J. (2010). Academic plagiarism: Explanatory factors from students' perspective. Journal of Academic Ethics, 8(3), 217-232.

Crisp, G. (2007). Staff attitudes to dealing with plagiarism issues: Perspectives from one Australian university. International Journal for Educational Integrity, 3(1), 3-15.

Dahl, S. (2007). Turnitin: The student perspective on using plagiarism detection software. Active Learning in Higher Education, 8(2), 173-191.

Davies, L. J. P., \& Howard, R. M. (2016), Plagiarism and the Internet. Fears, facts, and pedagogies. In T. Bretag (Ed.), Handbook of Academic Integrity (pp. 591-606). Singapore: Springer Reference Work.

Davis, M. (2013). The development of source use by international postgraduate students. Journal of English for Academic Purposes, 12(2), 125-135. 
Davis, M., \& Carroll, J. (2009). Formative feedback within plagiarism education: is there a role for text-matching software? International Journal of Educational Integrity, 5(2), 58-70.

Ellis, C. (2012). Streamlining plagiarism detection: the role of electronic assessment management. International Journal for Educational Integrity, 8(2), 46-56.

Evans, R. (2006). Evaluating an electronic plagiarism detection service: the importance of trust and the difficulty of proving students don't cheat. Active Learning in Higher Education, 7(1), 87-99.

Ferguson, K., Masur, S., Olson, L., Ramirez, J., Robyn, E., \& Schmaling, K. (2007). Enhancing the culture of research ethics of university campuses. Journal of Academic Ethics, 5, 189-198.Finnish Advisory Board on Research Integrity (2012) Responsible conduct of research and procedures for handling allegations of misconduct in Finland, retrieved 12 February 2014 from http://www.tenk.fi/sites/tenk.fi/files/HTK_ohje_2012.pdf

Finnish Advisory Board on Research Integrity (2009). Ethical principles of research in the humanities and social and behavioural sciences and proposals for ethical review. Helsinki. http://www.tenk.fi/sites/tenk.fi/files/ethicalprinciples.pdf. Accessed 29 June 2015.

George, D., \& Mallery, P. (2003). SPSS for Windows step by step ( $4^{\text {th }}$ ed.). Boston: Allyn and Bacon.

Gu, Q., \& Brooks, J. (2008). Beyond the accusation of plagiarism. System, 36(3), 337-352.

Gullifer, J., \& Tyson, G. A. (2010). Exploring university students' perceptions of plagiarism: a focus group study. Studies in Higher Education, 35(4), 463-481.

Hayes, N., \& Introna, L. (2005a). Systems for the production of plagiarists? The implications arising from the use of plagiarism detection systems in UK universities for Asian learners. Journal of Academic Ethics, 3(1), 55-73.

Hayes, N., \& Introna, L. D. (2005b). Cultural values, plagiarism, and fairness: When plagiarism gets in the way of learning. Ethics \& Behavior, 15(3), 213-231.Hirvela, A., \& Du, Q. (2013).’Why am I paraphrasing?”: Undergraduate ESL writers' engagement with sourcebased academic writing and reading. Journal of English for Academic Purposes, 12(2), 8798.

Howard, R. M. (1993). A plagiarism pentimento. Journal of Teaching Writing, 11, 233-245.

Howard, R. M. (1995). Plagiarisms, authorship, and the academic death penalty. College English, 57(7), 788-806.

Howard, R. M., \& Davies, L. J. P. (2009). Plagiarism in the Internet age. Educational Leadership, 66(6), 64-67. 
Hyytinen, H., Löfström, E., \& Lindblom-Ylänne, S. (2016). Beginning students’ problems in academic writing. Scandinavian Journal of Educational Research. http://dx.doi.org/10.1080/00313831.2016.1147072

Jamieson, S. (2016). Is it plagiarism or patchwriting? Toward a nuanced definition. In T. Bretag (Ed.), Handbook of Academic Integrity (pp. 503-518). Singapore: Springer Reference Work.

Jordan, S. R. (2013). Conceptual clarification and the task of improving research on academic ethics. Journal of Academic Ethics, 11(3), 243-256.

Jurowska, J.E., \& Thompson, J. P. (2012). “Opening doors early to academic integrity” - aiding the transition to and managing expectations of academic practice at University. International Journal for Educational Integrity, 8(2), 4-20.

Kaposi, D., \& Dell, P. (2012). Discourses of plagiarism: moralist, proceduralist, developmental and inter-textual approaches. British Journal of Sociology of Education, 33(6), 813-830.

Ledwith, A., \& Risquez, A. (2008). Using anti-plagiarism software to promote academic honesty in the context of peer reviewed assignments. Studies in Higher Education, 33(4), 371-384.

Lonka, K. (2003). Helping doctoral student to finish their theses. In L. Björk, G. Bräuer, L. Rienecker \& P. S. Jörgensen (Ed.), Teaching academic writing in European higher education. Studies in writing (pp. 113-131). Dorchrecht: Kluwer Academic Publisher.

Löfström, E. (2011). "Does plagiarism mean anything? LOL” Students' conceptions of writing and citing. Journal of Academic Ethics, 9, 257-275.

Löfström, E., \& Kupila, P. (2013). The instructional challenges of student plagiarism. Journal of Academic Ethics, 11(3), 231-242.

Martin, D. F. (2005). Plagiarism and technology: A tool for coping with plagiarism. Journal of Education for Business, 80(3), 149-152.

Mitchell, M.L., \& Jolley, J.M. (2013). Research Design Explained ( ${ }^{\text {th }}$ edition). Wadsworth, California.

Pecorari, D. (2003). Good and original: Plagiarism and patchwriting in academic second language writing. Journal of Second Language Writing, 12(4), 317-345.

Pickard, J. (2006). Staff and student attitudes to plagiarism at University College Northampton. Assessment \& Evaluation in Higher Education, 31(2), 215-232.

Power, L. G. (2009). University students' perceptions of plagiarism. The Journal of Higher Education, 80(6), 643-662. 
Roig, M. (1999). When college students' attempts at paraphrasing become instances of potential plagiarism. Psychological Reports, 84, 973-982.

Rolfe, V. (2011). Can Turnitin be used to provide instant formative feedback? British Journal of Educational Technology, 42(4), 701-710.

Savage, S. (2004). Staff and student responses to a trial of Turnitin plagiarism detection software. In Proceedings of the Australian Universities Quality Forum (pp. 2-7).

Serviss, T. (2016). Creating faculty development programming to prevent plagiarism: three approaches. In T. Bretag (Ed.), Handbook of Academic Integrity (pp. 551-567). Singapore: Springer Reference Work.

Street, B. (2004). Academic literacies and the 'new orders': implications for research and practice in student writing in higher education. Learning and Teaching in the Social Sciences, 1(1), 9-20. Sutherland-Smith, W. (2005). Pandora's box: academic perceptions of student plagiarism in writing. Journal of English for Academic Purposes, 4(1), 83-95.

Sutherland-Smith, W. (2014). Legality, quality assurance and learning: competing discourses of plagiarism management in higher education. Journal of Higher Education Policy and Management, 36(1), 29-42.

Tuhkanen, T. (Ed.) (2014). Sähköinen plagiaatintunnistus Suomen korkeakouluissa 2013 (In Finnish. Electronic plagiarism detection in Finnish higher education 2013). CSC IT Centre for Science.

Vaismoradi, M., Turunuen, H., \& Bondas, T. (2013). Content analysis and thematic analysis: implications for conducting a qualitative descriptive study. Nursing and Health Sciences, 15(3), 398-405.

Valentine, K. (2006). Plagiarism as literacy practice: Recognizing and rethinking ethical binaries. College Composition and Communication, 58(1), 89-109.

Vehviläinen, S., Löfström, E. \& Nevgi, A. (Accepted for publication 2017). Dealing with plagiarism in the academic community: emotional engagement and moral distress. Higher Education. DOI 10.1007/s10734-017-0112-6.

Walker, J. (2010). Measuring plagiarism: researching what students do, not what they say they do. Studies in Higher Education, 35(1), 41-59.

Weber-Wulff, D. (2016). Plagiarism detection software: promises, pitfalls, and practices. In T. Bretag (Ed.), Handbook of Academic Integrity (pp. 625-638). Singapore: Springer Reference Work. 
Wilkinson, J. (2009). Staff and Student Perceptions of Plagiarism and Cheating. International Journal of Teaching and Learning in Higher Education, 20(2), 98-105. 